\title{
Colonial Conflicts in Contemporary Northern Ghana: A Historical Prognosis of the British Colonial Factor in the Nawuri-Gonja and Mamprusi-Kusasi Conflicts
}

\author{
Cletus Kwaku Mbowura \\ Lecturer, Department of History, \\ University of Ghana, Legon
}

\section{Felix Y. T. Longi}

Senior Research Fellow, Institute for Interdisciplinary Research and Consultancy Services, University for Development Studies, Tamale, Ghana

\begin{abstract}
Northern Ghana has witnessed phenomenal increases in armed conflicts over the past three decades. Many of these conflicts are 'colonial conflicts' rooted in colonial policies, but some others have no reference to colonialism as they are occasioned by endogenous factors. The Kusasi-Mamprusi and Nawuri-Gonja conflicts are colonial conflicts whose historical roots are traceable to colonialism in Northern Ghana. This paper interrogates the British-sponsored political conferences held prior to the introduction of indirect rule in Northern Ghana, with special focus on the Mamprusi and Gonja conferences. The paper argues that the conferences sowed the seeds of the post-colonial MamprusiKusasi and Gonja-Nawuri conflicts.
\end{abstract}

Keywords: British colonialism, conferences, ethnic conflict, chieftaincy, Northern Ghana

This study focuses on the Nawuri-Gonja and KusasiMamprusi ethnic tensions within the broader picture of ethnic conflicts in Northern Ghana. Geographically, Northern Ghana comprises present-day Northern, Upper-East and Upper-West 
Regions and constitutes an area with different ethnic groups and traditional political systems. Historically, Northern Ghana was made up of the autochthones of the Nawuri, Konkomba, Nafelba, Vagla, Nchumuru, Komba, Mo, Tampluma, Sisala, Basari, among others, and the relative 'newcomers' such as, the Mole-Dagbani, Wala and the Gonja. Other notable ethnic groups in Northern Ghana include the Frafra, Bimoba, Busansi, Talensi, Bisa, Kusasi, Kasena, Bulsa, Anufo (Chakosi), Dagarba and Lobi. Culturally and linguistically, Northern Ghana is pluralistic though Rattray (1932, p.1) regards the region as a more or less 'homogeneous cultural and - to a lesser extent - linguistic area, rather than a mosaic comprising of a welter of tongues and divergent cultures.' Generally, the pre-colonial political relations of these diverse ethnic groups in Northern Ghana were cordial, though some of the relations were in the form of overlord-subject, conquerorconquered and landowners-landless arrangements.

It is common knowledge that since the last decade of the Twentieth Century, Africa has, for various reasons, experienced phenomenal increases in armed conflict with destructive consequences. Many sub-regions of the continent have been enmeshed in civil wars and other forms of conflict, putting them in a state of turmoil and anarchy. In the West African sub-region, Liberia, Sierra Leone, La Côte d'Ivoire (The Ivory Coast) and Mali have been embroiled in conflicts in the last thirty years due to struggle for political space and power. While these countries were being torn apart by the scourge of conflicts, Ghana enjoyed relative peace and political stability, attracting the designation, 'the oasis of peace in West Africa.' However, the general assumption that Ghana is an oasis of peace is simplistic for it fails to critically interrogate the political situation in Northern Ghana. Over the past four decades, Northern Ghana has been in a state of turmoil as it continues to grapple with armed ethnic and religious conflicts. Since 1980, various parts of Northern Ghana have witnessed intermittent eruptions of inter-ethnic conflicts, which led to phenomenal destructions to lives and properties. In the Northern Region alone, there have been wars between the Nanumba and the Konkomba in 1981, 1994 and 1995; between the Bimoba and the Konkomba in 1984, 1986 and 1989; between the Nawuri and the Gonja in 1991 and 1992; and between the 
Konkomba, the Nawuri, the Bassari and the Nchumuru, on the one hand, and the Gonja on the other in 1992. In the Upper-East Region, there have been intermittent outbreaks of war between the Kusasi and the Mamprusi over the past two decades. This paper attempts to examine the conundrum of ethnic conflicts in Northern Ghana with special focus on the Kusasi-Mamprusi and NawuriGonja conflicts. By dissecting the antecedents of the conflicts, the paper argues that the Kusasi-Mamprusi and the Nawuri-Gonja conflicts are 'colonial conflicts': the colonial system of the British created the structures of the conflicts (Brukum, 2001). This study focuses on the Nawuri- Gonja and the Kusasi-Mamprusi conflicts for two main reasons. In the first place, unlike most conflicts in Northern Ghana, the Nawuri-Gonja and the Kusasi-Mamprusi conflicts have defied attempts to resolve them, thus protracting and perpetuating them. Secondly, while the causes of these conflicts are rooted in colonial policies, the conflicts have not only found expressions and furnace in the post-colonial periods but also have been recurrent.

\section{Understanding Armed Conflicts in Africa}

Studies have posited conflicts in Africa within different theoretical contexts. Until the end of the Cold War, conflicts in Africa were seen as un-extinguished bushfires from the Cold War. Wars and conflicts in African history during the Cold War were generally seen by many scholars as a monopolised phenomenon of the Super Powers. This proposition was anchored on the view that every conflict in Africa was, in a way, shaped by the ideological struggle between the East and the West, and that the chief protagonists - the United States and the Soviet Union fought wars by proxy in Africa (Richards, 2005). There was also the contention that the Super Power balance of nuclear terror kept the lid on many local conflicts, but once the Cold War competition ended, endemic hostilities reasserted themselves, and this saw the upsurge of ethnic conflicts in Africa in the 1980s and 1990s as a reaction to events in Eastern Europe (Richards, 2005). The collapse of the old order in Eastern Europe in the late 1980s and early 1990s thus had a tremendous impact on the fragile nationstates of Africa. 
Scholarship has also linked conflicts in Africa to colonialism. The argument, according to Lentz and Nugent (2000), is that prior to colonisation,

Africans belonged simultaneously to a bewildering
variety of social networks - nuclear and extended
families, lineages, age sets, secret societies, village
communities, diasporas, chiefdoms, states and empires.
Loyalties and identities were complex, flexible and
relatively amorphous, and certainly did not add up to
clearly demarcated tribes living in well-defined and
bounded territories. These multiple identities ... continued
into the colonial period. (p. 5)

Many historians attribute the causes of armed post-independence conflicts in Africa to colonialism. They argue that the invention of ethnic groups was a product of colonial policy, though they acknowledge the fact that ethnicity in Africa was "nourished by the active participation of African actors who moulded political and cultural traditions in accordance with their own self-interest' (Lentz \& Nugent, 2000, p. 5). This argument stresses the disparate nature of African societies as one of the sources of conflicts on the continent. The view is that conflicts in Africa are an inevitable consequence of the multi-ethnic nature of African states which necessarily leads to a clash of identities and cultures. Ethnic pluralism in Africa creates conflict structures and conditions for the mobilisation of ethnic and cultural resources for violent conflict (Richards, 2005, pp. 1-25). This argument has been used by some scholars to dissect conflicts in post-colonial Northern Ghana. Scholars, such as Skalnik (1983, 1989), Bombande (2007) and Brukum $(2001,2007)$, have pointed to the complicity of the colonial enterprise in contemporary conflicts in Northern Ghana. The thrust of their argument is that the colonial enterprise imposed notions of state and state power on Northern Ghana without taking cognizance of the conceptual differences in outlook between centralised and non-centralised societies. They further argue that colonialism, with its policy of indirect rule, was the major cause of inter-ethnic conflicts in Northern Ghana because it created lots of antagonisms, grievances and festering relations between ethnic groups. Finally, they argue that in some instances state actors of 
the colonial regime themselves have fomented or condoned war. The above interpretation of conflicts in Africa is significant to this paper because it gives clues that 'ethnic pluralism in Northern Ghana creates an environment for constant engagement of rival ethnic interests' (Mbowura, 2014, pp. 1505-1506). In addition, it helps to understand the extent to which interactions between the state and societies in Northern Ghana generate rival interests among the societies to secure public resources from those in authority at the political centre, and how that could produce conflicts among the rival societies.

This paper is placed within the broader argument of the complicity of the colonial government in conflicts in Africa. It argues that the colonial policy of indirect rule with its attendant of traditional political structures and relations sowed seeds of conflict between the Nawuri and the Gonja, and the Kusasi and the Mamprusi of Northern Ghana alike. Unlike existing literature (Skalnik,1983, 1989; Bombande, 2007; Brukum, 2001, 2007) on the complicity of the colonial governments in Africa which focuses on the general colonial super-structure, this paper focuses on colonial policy framework which turned hitherto independent societies of the Nawuri and the Kusasi into subjects of the Gonja and the Mamprusi, respectively. 


\section{Map of Ghana showing the three Northern regions.}

(Source: Researchgate.net Accessed on October 13, 2016)

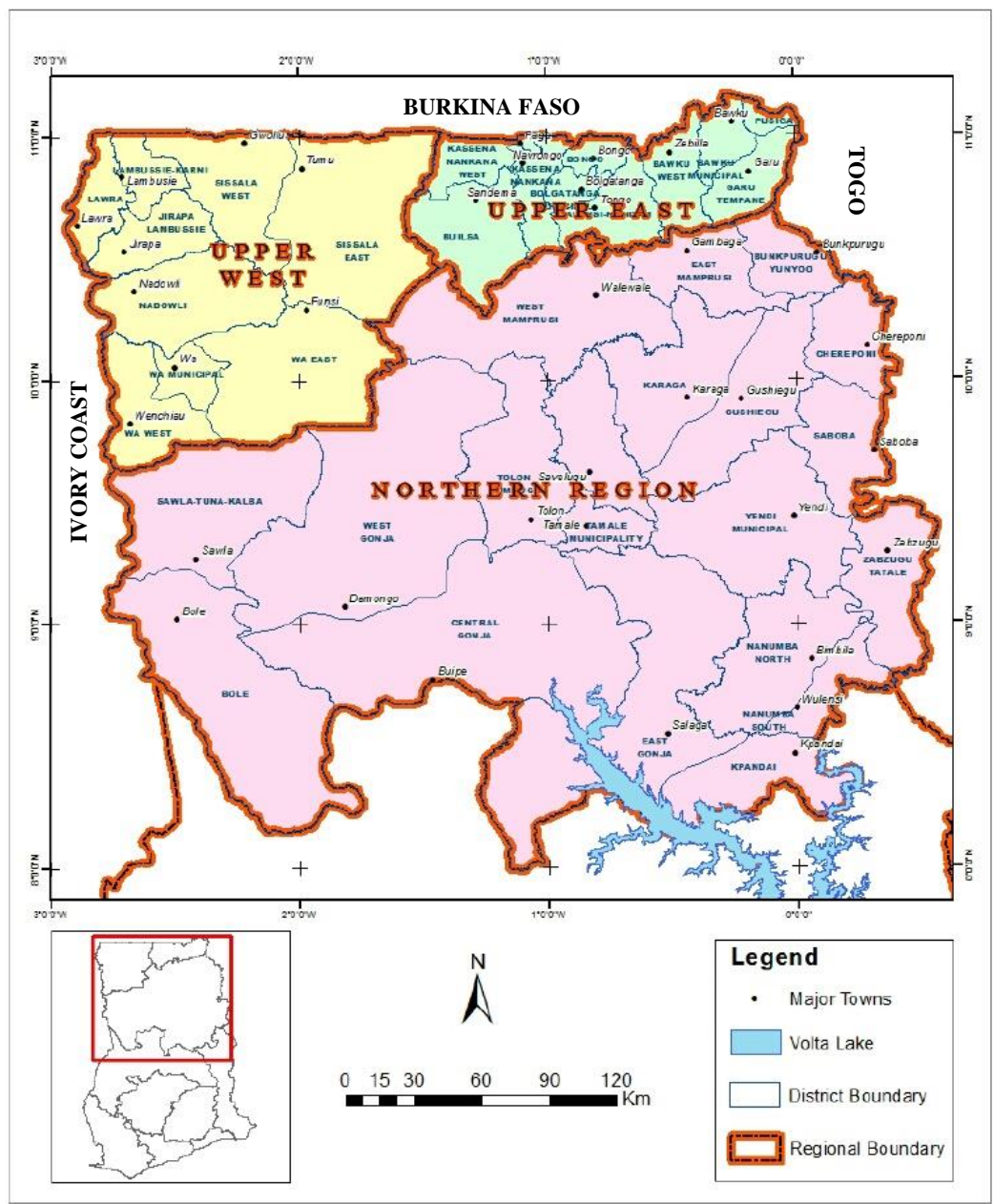

\section{Methodology}

This study adopted the orthodox approach to historical enquiry that combines archival research with published materials and historical memories. Data for the paper were qualitative derived from systematic enquiry, which were analysed and interpreted to understand the colonial phenomenon and factor in contemporary conflicts in Northern Ghana. The study made a wide use of primary sources obtained from a corpus of first-hand or 
original data on colonialism, Northern Ghana and conflicts. By and large, the study made use of primary documents in the Public Records Administration and Archival Division (PRAAD) in Accra and Tamale. Use was also made of primary materials, such as reports of committees of enquiry. Finally, data were carefully gleaned from a variety of monographs, books, articles and public memories on colonialism, Northern Ghana, conflicts, NawuriGonja and Kusasi-Mamprusi relations.

\section{From The Pre-colonial Situation to the Colonial Era}

Bawku, located in the north-easternmost corner of Ghana, has been at the centre of the Mamprusi-Kusasi imbroglio. Available historical evidence indicates that the Kusasi were the autochthones of Bawku and its environs, and that the Mamprusi met the Kusasi already inhabiting the area when they arrived (Hilton, 1962). The area also attracted the arrival of the Bimoba, Bisa and Busansi. The commercial importance of Bawku which served as a catalyst for the penetration of people of different ethnic background to the area cannot be underestimated. Existing narratives (Hilton, 1962; Drucker-Brown, 1995; Amadu, 2002; Lund, 2003; Awedoba, 2009) on the history of Bawku suggest that in the pre-colonial times the town was a market centre which later, during the colonial era, also grew into a busy trading post near two international borders, Togo to the East and Burkina Faso (former Upper Volta) to the North, though Benin (former Dahomey) and Niger also were not too distant. By its strategic geographical location and its vibrant commercial activities, Bawku became a polyglot of immigrants from other parts of Africa, who settled in the town to take advantage of economic opportunities there. These immigrants came to join the Kusasi, Mamprusi, Busanga, Bisa and the Bimoba already well established in the area (Syme, 1932).

Narratives (Drucker-Brown, 1995; Lund, 2003; Awedoba, 2009) on the primordial beginnings of the Mamprusi-Kusasi conflict link it to the contest for the Bawku Skin though the issue of allodial land rights cannot be completely ruled out. In their book African Political Systems, Fortes and Evans-Pritchard (1940) categorised the political systems in Africa into two - states with centralised authority and the uncentralised ones whose features of 
government are defined in local lineage rather than in administrative terms. Scholars, largely anthropologists, have applied these classifications to societies in Northern Ghana. The Mole-Dagbani, Gonja and Wala have been described as centralised, that is, societies with systems of government by which jurisdiction is territorial and based on chieftaincy with a paramount chief serving as the repository of authority. On the other hand, the rest of the societies in Northern Ghana, including the Kusasi, were described as non-centralised societies, lacking in the territorial unit defined by administrative terms and the notion of chieftaincy.

The general conception is that the Mamprusi immigrated into Bawku with advanced ideas of chieftaincy, and that chieftaincy was an established institution among the Mamprusi long before the imposition of colonial rule. The Mamprusi had a hierarchy of chiefs or ' $\mathrm{Na}$ ' with the Nayiri as overlord and the tendanas operating alongside the $\mathrm{Na}$. As secular rulers, the Nayiri and his sub-chiefs enforced law and order through adjudication of cases. Contrarily, Kusasi society prior, to contacts with the Mamprusi and the imposition of colonial rule, was said to be noncentralised, though recent scholarship (Tuuray, 1982; Mbowura, 2013a) shows that it was inappropriate to describe the political systems of some of the ethnic groups as acephalous as there is evidence of the historicity of the institution of chieftaincy or the concept of political leadership among them. The Kusasi did not acknowledge a centralised political authority headed by one individual as supreme ruler manipulating a centre of power that consisted of a court and council of elders. Their societies were headed by tendanas (earth priests) who were spiritual leaders and assisted by different clan and family heads. They offered sacrifices to the land gods to secure their sources of livelihood and their authority did not go beyond imposing spiritual and moral sanctions on wrongdoers. In spite of these differences in political organisation, the two groups lived peacefully prior to colonial intrusion. The tendanas operated alongside the Mamprusi chiefs playing different roles, and there was no evidence of Mamprusi suzerainty over the Kusasi or inhabitants of Bawku and its environs (Syme, 1932). 
The conflict structures of the Kusasi-Mamprusi and Nawuri-Gonja were created by the colonial authorities, but there is a dichotomy between the issues of dispute. The KusasiMamprusi conflict was triggered by a chieftaincy dispute, but that of the Nawuri and the Gonja erupted over allodial land rights to Kpandai and its environs. In the Kpandai area, as is the case of other Ghanaian societies, the modes of measuring allodial land rights are embedded in the historical traditions of the people. By right of autochthony and autonomy, allodial land rights in the Kpandai area in the pre-colonial period resided in the Nawuri. However, the area's encounters with the colonial enterprise led to the evolution of new constructs of allodial rights in land, which challenged established traditions and provided the opportunity for the immigrant Gonja community to appropriate land (Mbowura, 2012).

In the early pre-colonial period, Kpandai and its environs in Northern Ghana were inhabited by the Nawuri (the autochthones) and the Gonja (the immigrants). The Nawuri claim autochthony and trace their origins to the Afram Plains and Larteh-Akuapem in Southern Ghana (Mbowura, 2012). The Gonja, on the other hand, claim descent from Ndewura Jakpa and his invading founders of the Gonja kingdom and trace their origins to Mande in present-day Mali (Braimah \& Goody, 1967). Narratives on Nawuri-Gonja encounters in the pre-colonial period suggest that the Gonja peacefully entered the Kpandai area in the seventeenth century as immigrants; they did not arrive as invaders as was characteristic of Gonja penetration into most parts of Northern Ghana (Ampiah, 1991; Maasole, 2006; Awedoba, 2009; Mbowura 2002, 2012;). The narratives further suggest that prior to the Gonja arrival, the Kpandai area was long inhabited by the Nawuri, and that the Gonja neither conquered the Nawuri nor did the two groups fight each other in the pre-colonial period. On the contrary, the two ethnic groups co-existed as political allies (Ampiah, 1991; Mbowura, 2002; Awedoba, 2009). This politically symbiotic relationship between the Nawuri and the Gonja was destroyed by the German and British colonial enterprise, and from its ruins emerged a subject-overlord relation between the two ethnic groups. For the sake of political expediency, the colonial authorities invested political authority in 
the Kpandai area in the Gonja in contravention of history, customs and tradition (Mbowura, 2012, 2013, 2014). The creation of Gonja authority over the Nawuri as a colonial agency gave a new face to Nawuri-Gonja encounters. In the pre-colonial period, the notions of the boundaries of political authority and allodial land rights in most parts of Northern Ghana were intertwined. Applying this notion to their colonially-created political authority, the Gonja began to claim and exercise allodial land rights in the Kpandai area. The attendant consequence of the Gonja posture was the emergence of conflicting claims to allodial land rights in the Kpandai area between them and the Nawuri. Both ethnic groups used history as 'weapons' to advance their claims.

\section{Colonial Reconfiguration of States and the Building of Conflict Structures in Bawku}

Towards the end of the Nineteenth Century, the British consolidated their occupation of Bawku and Mamprugu ${ }^{1}$ with the establishment of administrative stations in both areas. The arrival of the British and their hasty endorsement of the existing political arrangement as told by the Nayiri enabled the Mamprusi to consummate their political suzerainty over the Kusasi. British colonialism, looking for easy and convenient ways to administer the vast territories they had acquired by 1900, initially administered their territories directly, but in the 1930s adopted the indirect rule system which enabled them to govern through the existing traditional rulers or leaders. Given the prevailing misconception that the lands occupied by the Kusasi, Busansi and Frafra were all part of the Mamprugu territory, the British colonial administration not only endorsed the six Mamprusi chiefs appointed by the Nayiri in the Kusasi area, but also appointed new canton chiefs in areas where none existed, some of whom were Kusasi (PRAAD, Tamale, NRG 8/2/214). The introduction of indirect rule in the 1930s necessitated the implementation of the amalgamation system. To this end, political conferences were held to reconfigure states and societies in Northern Ghana. By far,

1 The terms Mamprugu, Mamprusi and Mampruli are terms used to refer to the state, ethnic group and language of the Mamprusi of Northern Ghana, respectively. 
the Kusasi Conference of March 1931 and the Mamprusi Conference of December 1932 were the most important as they had significant consequences on Mamprusi-Kusasi relations (PRAAD, Accra, ADM 56/1/198).

Events before and during the Kusasi Conference of March 1931 appeared to have been manipulated or stage-managed by the colonial administration and the Nayiri to guarantee a certain predetermined outcome, that is the election of the Mamprusi Bawku chief as head chief of all Kusasi. As part of the colonial administration's policy to support chiefs who were of good behaviour and promote the evolution of a strong Mamprusi state, it popularised the Bawku chief (who later became the Bawku Naba after the conference) for thirty (30) years. This support for the Bawku chief dates back to 1910 when the Nayiri, Na Awibiga, hinted that the chief was being groomed to become the head of all chiefs in the Kusasi District (PRAAD, Accra, ADM 56/1/277), an idea which received the backing of the colonial administration. Consequently, the Bawku chief was treated as superior to his colleagues even before the Kusasi Conference of 1931, a position other Kusasi chiefs accepted voluntarily or compulsorily. This affected the thinking of the Acting District Commissioner at the time, who warned against electing any other person than the Bawku chief (PRAAD, Accra, ADM 56/1/198).

Following the refusal of the Kusenaba, Naba Ayebo (an ethnic Kusasi), to be elected paramount chief of the Kusasi Traditional Area, the lot fell on the Bawku Na (a Mamprusi), much to the relief and excitement of the District Commissioner, who presided over the conference (Hilton, 1962; Akologo, 1996; PRAAD, Accra, ADM 56/1/198). His election was confirmed and blessed by the Nayiri in that same year. As part of the new arrangements, it was decided that henceforth only the Bawku $\mathrm{Naba}^{2}$ would be installed by the Nayiri and he would in turn install the other five Mamprusi chiefs as well as the newly created set of (12) Kusasi canton chiefs. A new hierarchy was thus created in 1931. Out of the nineteen chiefs in attendance, fourteen of them

2 Bawku Naba is the paramount chief of the Bawku Traditional Area. The Nayiri is the paramount chief of the Mamprusi while the Kusenaba is the chief of one of the seventeen cantons in the Bawku Traditional Area. 
were ethnic Kusasi, but a Mamprusi was elected as the Bawku Naba for a number of reasons. First of all, they understood that electing a resident Mamprusi chief as Bawku Naba would please the colonial administration and the Nayiri and guarantee them continued enjoyment of their positions with their associated perquisites. Again, the chiefs stood to benefit from the election of a Bawku-based head chief with power to enskin without the necessity of their travelling to Nalerigu ${ }^{3}$ for investiture at the Nayiri's palace, a tradition which involved a great deal of cost and personal sacrifice (PRAAD, Accra, ADM 56/1/198). Besides, having made Bawku the principal town since their arrival there, the British colonial authorities found it uncongenial and politically inexpedient to have the head chief living somewhere else since that could create administrative problems. Furthermore, the colonial administration and the Nayiri supported the Bawku Naba because they trusted him to promote the ultimate objective of restructuring the Mamprusi state (PRAAD, Accra, ADM $56 / 1 / 198)$.

\section{Implications of the Changes}

As previously stated, the changes initiated at the conferences were varied and significant for two reasons. Firstly, the elective principle replaced the appointive method which hitherto was exercised solely by the Nayiri. From March 1931, it became the practice for all the chiefs to be elected by their headsmen and tendanas before they were confirmed by the investing authority (Bawku Naba). This elective principle was used as a basis and reference point for challenging the Nayiri's exercise of the appointive principle in the choice of Yeremea as Bawku Naba in 1957. The unsuccessful Mamprusi princes questioned the process of Yeremea's nomination describing it as being at variance with established practices in vogue since the 1931 Conference (PRAAD, Tamale, NRG8/2/138).

Furthermore, the Bawku Naba who was previously equal in rank to the other 17 chiefs was elevated above his colleagues to the position of head chief with the authority to install the other

\footnotetext{
3 Nalerigu is the capital of the Mamprugu state, which is also the seat of the Nayiri, the paramount chief of the Mamprusi..
} 
chiefs in Kusasi. This in itself had various implications and ramifications. The installation fees which used to be paid to the Nayiri would henceforth be claimed by the Bawku Naba. Besides, the other chiefs in Kusasi were relieved of the burden of trekking to the Nayiri's court in Nalerigu for installation which entailed much more expenses. In addition, this detachment also reduced the frequent contact between the Nayiri and his subjects and consequently, undermined his authority as he no longer dealt directly with them.

The Kusasi Conference was followed by the Mamprusi Conference of 1932 which ratified the decisions of the Kusasi Conference and led to the establishment of vague relationships between chiefs and certain ethnic groups for purposes of political expediency. These superficial arrangements created unnatural superior-subordinate hierarchical relations and their attendant problems which resulted in tensions and eventual clashes in the 1950s. The Bawku Naba was also later elevated to the status of a divisional chief under the Nayiri thus integrating and effectively subordinating the Kusasi into the Mamprusi kingdom for the first time. It is the resistance of the Kusasi to this status quo and the determination of the Mamprusi to maintain it that set the stage for ethnic frictions.

By the 1932 arrangement, the Kusasi became subordinates and occupied marginal and irrelevant positions in the British colonial administrative structure and the general scheme of things. The statuses of chiefs were in many cases elevated beyond what traditional systems assigned them. The crucial role chiefs played in the direct and indirect rule system necessitated the creation of chieftaincy where none existed or the recognition of the authority of a chief even if the basis for the exercise of the chief's powers was unjustifiable. The creation of eighteen cantonal chiefs that included the chief of Kusasi, who were all subordinated to the Mamprusi Bawku Naba, now a sub-chief of the Nayiri, was the brain-child of British colonial administrative restructuring confirmed at the Mamprusi Conference of 1932.

In the case of Bawku, specifically, the Mamprusi hegemony was recognised as the colonial government accepted the Mamprusi Bawku Naba as primus inter pares after the Kusasi Conference of March 1931. Less than a decade after the British 
sponsored political conferences and amalgamations, the unforeseen consequences of the changes made in 1931 and 1932 became manifest as the Nayiri began to contemplate a reversal to the previous arrangement whereby he directly installed all 18 canton chiefs in Kusasi, an idea which was a recipe for conflict.

Two major reasons explain why the Nayiri had a change in disposition towards the colonial power structure established in Bawku and its environs. In the first place, two years after the Kusasi Conference of 1931, the revenue accruing to the Nayiri's treasury decreased drastically. In 1933, the Nayiri complained that he was not receiving substantial revenue from the Kusasi chiefs as was the case before 1931. He contemplated withdrawing the Bawku Naba's privilege of enskinning sub-chiefs in Kusasi and activated the argument that his fetish required him to personally enrobe all the sub-chiefs at his palace in Nalerigu, obviously in the hope that those presenting themselves would bring along substantial offerings or gifts besides the statutory installation fees. Furthermore, the Nayiri was beginning to lose his spiritual bond and authority over the sub-chiefs because he no longer frequently interacted with them directly through the personal installation of chiefs.

A reversal to the old order required the absolute approval of the sub-chiefs. However, their position on the matter was unfavourable as all of them unanimously resolved not to revert to the old order. The response of the chief of Sinnebaga vividly illustrated the position of the sub-chiefs as he expressed the optimism that his heirs would continue to enjoy the new political dispensation (PRAAD, Accra, ADM56/1/198). Similarly, the Chief of Binaba expressed disgust at serving two overlords at the same time, the Bawkunaba and the Nayiri (PRAAD, Accra, ADM56/1/198). These events which were a consequence of the 1931 Kusasi Conference and the 1932 amalgamations were suggestive of a growing insubordination by Kusasi canton chiefs to the Nayiri. They also represented a determination by the subchiefs to demystify the ancient mystery surrounding the Nayiri's fetish as a requirement for chiefs holding his 'Nam' before they could function successfully and also marked the beginning of challenges to the Nayiri's authority which culminated in the clashes of 1957. 
The political subordination of the Kusasi continued for close to three decades until June 1957 when the situation threatened to boil over. The Kusasi had blamed the British for not only imposing Mamprusi chiefs on them, but also compelling them to recognise the overlordship of the Nayiri. The forced amalgamation of the Kusasi with the Mamprugu Kingdom in 1932 deprived the Kusasi of their traditional autonomy and provided the Mamprusi with a historical justification for perpetuating the master-subordinate relationship long after the exit of the British colonial administration in 1957. Though the Kusasi found no suitable opportunity for expressing their frustration until after independence, the Kusasi feelings of suppression between 1932 and 1957 set the stage for the post-independence clashes. Mamprusi-Kusasi relations began to take a turn for the worse after the 1932 political amalgamations which subjugated the Kusasi to the Mamprusi. Kusasi sources affirm that the Mamprusi began to treat the Kusasi with disdain after the 1932 Conference which made them subjects (Akologo, 1996). This treatment ranged from taxation, tribute payment and forced labour to marginalisation. Contribution by subjects towards the reception of official guests was a common legitimate practice throughout the protectorate. Apart from the Government approved taxes, the Kusasi were required to send a percentage of their annual harvest to the Bawku Naba. Such cases of abuse of the system and highhandedness became widespread throughout the Northern Territories. Some forms of taxation or tribute had been paid by some Kusasi to the Nayiri prior to 1931 , but such payments had been limited to Mamprusi chiefs in the Kusasi area and Kusasi chiefs holding the Mamprusi 'Nam' (chiefship) from the Nayiri (PRAAD, Accra, ADM 56/1/198).

Again, in the exercise of his duty to mobilise labour for public works, the Bawku Naba abused his authority by diverting labourers, mostly Kusasi, to work on his farm and perform other domestic duties (Nachinaba, 2002). Before 1932, the Kusasi, of their own volition, occasionally assisted the Bawku Naba on his farm. After 1932, this was done under some compulsion. This abuse of authority, coupled with the marginalisation of the Kusasi, became their major grievance, thus creating tension between the 
two ethnic groups, tension which finally degenerated into a number of armed conflicts in the post-colonial era.

\section{Subordinating the Nawuri to the Gonja: the German and British Factors}

Unlike the situation of the Kusasi in Bawku, the reconfiguration of political structures initiated by the British in Kpandai and its environs had its antecedents in German political policy. The area was under German colonial administration and administered as an enclave of German Togoland between 1899 and 1914. In configuring administrative territories, German colonial authorities included the Kpandai area in the Kete-Krachi District, which comprised the Krachi, Nanumba, Nawuri, Nchumuru, Achode and Adele traditional areas. The principle of political expediency forced the German colonial authorities to interfere in the traditional norms and patterns of traditional observance in the Kpandai area. Using the 'warrant' system as a basis of investing traditional rulers with paramount power, the German colonial authorities made an immigrant Gonja the paramount ruler of the Kpandai area. As was the case of the warrant chiefs in Eastern Nigeria under British rule, the Germans, instead of recognising the Nawuri paramount chief, ignored history but rather issued a 'warrant' to Kanankulaiwura Mahama Karatu (the Gonja head chief in the Kpandai area) to exercise authority in the Kpandai area that he had never exercised before (Dixon, 1955). This was because the Germans considered the Nawuri to be unenlightened, primitive, poor and incapable of evolving an effective political administration (PRAAD, Accra, ADM 11/1/1621). By contrast, Mahama Karatu who was literate in Arabic, was described as enlightened and an 'experienced man who had travelled much in the course of trade' (Braimah \& Goody, 1967, p. 70). In short, by the stroke of a pen and against history and tradition, the Germans made the Kanankulaiwura the repository of traditional authority in the Kpandai and subordinated the Nawuriwura to him. The result was that Kanankulaiwura Mahama Karatu and his successors were regarded by the Germans and later the British as overlords and superior to Nawuri chiefs (Mbowura, 2012). 
In 1919 the Kpandai area came under British colonial administration following the partition of German Togoland between France and Britain after the end of World War I. Initially, the entire Kete-Krachi District was placed under the Asante Province, but was later carved out from Asante Province in 1923 and added to the Northern Territories due to problems of poor communication and transportation network (Bening, 1999; PRAAD, Tamale, NRG8/3/53).

\section{The Yapei Conferences}

In 1923, 1930 and 1932, respectively, three conferences were held at Yapei to draft a scheme for the introduction of indirect rule in the Gonja kingdom. Unlike the Kusasi case, no separate conferences were held for the Nawuri and the Gonja; neither did the Nawuri attend the Yapei Conferences (Mbowura, 2012). The 1923 Yapei Conference marked the first attempt by the British colonial authorities to bring the Gonja together as a united people. Prior to the conference, the central authority of the Gonja (the Yabumwura) was weak. The conference was attended by Kanankulaiwura Mahama Karatu, who used the opportunity to meet with other Gonja chiefs for the first time. The discussions at the conference had forebodings for the Kpandai area (PRAAD, Accra, ADM 56/1/324). The first was Gonja claims to Nchumuru which prefigured their intentions towards the Kpandai area. They demanded the inclusion of Nchumuru lands in the Gonja District, which were at the time in the Kete-Krachi District (PRAAD, Accra, ADM 11/1380). Though the Gonja chiefs did not lay direct claim to Nawuri lands in the Kpandai area, it signaled their intentions to appropriate territories in the Kete-Krachi District with some historical connection, however tenuous, to the Gonja kingdom.

In May 1930 the colonial authorities convened another conference at Yapei to draft modes of succession and a constitution for Gonja. It was organised under the auspices of Duncan Johnstone, the Acting Commissioner for Southern Province, and was attended by a number of Gonja chiefs, including the Kanankulaiwura, Mahama Karatu. One of the key issues raised in connection with the 1930 Conference was about representation for the Nawuri and the Nchumuru as distinct 
groups. One account states that the Gonja opposed it, maintaining that the Nawuri representation was through the Kanankulaiwura (Ampiah, 1991).

In effect, the Gonja insisted that the Nawuri had no autonomy. Another account maintains that the Nawuri sent their representatives to the conference, though their names did not appear in the records of the proceedings (Ampiah, 1991, Part II, p. 22; PRAAD, Accra : ADM 11/1/1380). The Nawuri dispute that and also maintain that they were not invited to the 1930 conference at all; nor did they attend or send representatives to it. The 1930 Conference drew up a constitution to formalise the lines of succession to the Yagbum Skin of the Gonja. It also constituted the Gonja District, leading to the creation of a 'new Gonja kingdom' under British colonial rule. Sovereign societies such as those of the Nawuri and the Nchumuru were brought under the newly constituted Gonja kingdom (PRAAD, Accra, ADM 11/1/1380). As a follow-up to the 1930 Conference, another conference was held at Yapei in 1932 which discussed the fiscal policy of the Gonja District. In attendance was Kanankulaiwura Mahama Karatu, invited in his capacity as the overlord of the Kpandai area (PRAAD, Accra, ADM 11/1/1380).

The Yapei Conferences laid the foundation for the NawuriGonja conflict as they sanctioned the inclusion of the Kpandai area into the Gonja District or kingdom. By endorsing the integration of the Kpandai area into the Gonja kingdom in the interest of administrative expediency, the conferences laid the foundation for Gonja appropriation of the allodial land rights to Nawuri lands in the Kpandai area. In addition, it consigned the Nawuri to a subject status and made the Gonja rulers over them. Thus the fate of the Nawuri in all issues concerning their land and administration were placed entirely in the hands of Gonja chiefs. As political overlords, the Gonja claimed allodial land rights to Nawuri land in the Kpandai area, leading to a protracted dispute over allodial land rights between the Nawuri and the Gonja, a dispute which reached a crescendo when the two ethnic groups took to arms in 1991 and 1992.

The conferences gave considerable power to the Yabumwura and his sub-chiefs over areas in the same manner that subjects brought under Gonja rule. It bestowed on the Gonja ruling 
class a considerable amount of power, which allowed them to exercise a measure of their 'old jurisdiction and settle civil and criminal cases in their own courts' (PRAAD, Accra, ADM 11/1/1380). The conferences did not acknowledge the jurisdiction of Nawuri chiefs in the Kpandai area as they were not recognised by the colonial government. The result was that well into the 1990s, the Gonja refused to recognise chieftaincy as it existed among the Nawuri (Ampiah, 1991; Mbowura, 2013). Nawuri effort, in the colonial and post-colonial periods, for their political leaders to be recognised as 'chiefs' by the central

government, the local government structure and the Gonja was unsuccessful. This left the door to conflict wide open and hence, the outbreak of war between the two ethnic groups in 1991 and 1992.

The conferences also empowered Gonja chiefs to collect taxes from the Nawuri and impose tributes on them (PRAAD, Accra, ADM 11/1/1380). Since the 1930s, the Gonja have imposed tributes of all types on the Nawuri. These took the form of cash, foodstuff, baskets of fish, hind legs of animals and labour services (Dixon, 1955; Ampiah, 1991). Indeed, the 'labour tax' demanded by the Kanankulaiwura caused a lot of discontent among the Nawuri as it turned them from legitimate owners of their territory to serfs, and was one of their main grievances against the Gonja (Ampiah, 1991). It was these payments of taxes that gave an economic dimension to the wrangles between the Nawuri and the Gonja, which subsequently degenerated into open hostilities between them in 1991 and 1992.

\section{Conclusion}

The study has established that in the pre-colonial period, Bawku was a buoyant commercial centre, and it was inhabited by the Kusasi and immigrants such as the Mamprusi, Busanga and the Bimoba. There was no record of conflict between the ethnic groups. There was political harmony in Bawku in the pre-colonial period as all the ethnic groups lived in peace. Similarly, there was peace and tranquility in the Kpandai area in the pre-colonial period as both the Nawuri and the Gonja immigrants lived in harmony and co-existed as political allies. There were no traces of wars between the autochthones and the immigrants of the two 
respective areas, nor was there any evidence of Mamprusi and Gonja conquest of the Kusasi and the Nawuri in the pre-colonial period, respectively.

In the 1930s, the British colonial authorities applied the policy of amalgamation to the disparate societies and fluid ethnic groups in Northern Ghana in order to create convenient administrative structures for the workability of the indirect rule system. The Nawuri and the Kusasi were amalgamated with the Gonja and the Mamprusi, respectively. Prior to the amalgamation of societies and states in Northern Ghana, various conferences were convened by the colonial authorities for the various ethnic groups and traditional states. Whereas separate conferences were held for the Kusasi in 1931 and the Mamprusi in 1932, no similar conferences were convened for the Nawuri. Instead, three conferences were held successively for the Gonja which culminated in the amalgamation of Nawuri territory with the Gonja kingdom. The amalgamation of the Kusasi and the Nawuri to the Mamprusi and the Gonja, respectively, created different jurisdictional disputes. While the amalgamation policy created a chieftaincy dispute between the Kusasi and the Mamprusi in Bawku, it created a dispute over allodial land rights in the Kpandai area between the Nawuri and the Gonja. The products of these disputes were the armed conflicts which erupted in the postcolonial period between the Kusasi and the Mamprusi in Bawku over the Bawku Naba Skin, and between the Nawuri and the Gonja in the Kpandai area over allodial land rights.

This paper provided readers and policy-makers a perspective on the colonial creation of the Kusasi-Mamprusi and the Nawuri-Gonja conflicts in Northern Ghana. Its insight into the colonial responsibility for the conflicts provides an intellectual resource for readers and adequately equips policy-makers with the knowledge of the antecedents of the conflict to help them work out tangible solutions to pre-empt the recurrence of these conflicts. 


\section{References}

Akologo, D.A. (1996). A short history of the Kusasi of Bawku. (Undergraduate Dissertation). University of Ghana, Legon, Ghana.

Ampiah, J. (1991). Report of the Committee of Inquiry into the Gonjas, Nawuris and Nanjuro dispute. Accra, Ghana: Government of Ghana.

Awedoba, A.K. (2009). An ethnographic study of Northern Ghanaian conflicts: Towards a sustainable peace. Accra, Ghana: SubSaharan Publishers.

Brukum, N.J.K. (2001). The guinea-fowl, mango and pito wars: Episodes in the history of Northern Ghana, 1980 to 1991. Accra, Ghana: Ghana Universities Press.

Brukum, N.J.K. (2007). Chieftaincy and ethnic conflicts in Northern Region of Ghana, 1980-2002. In S. Tonah (Ed.), Ethnicity, conflicts and consensus in Ghana (pp. 98-115). Accra, Ghana: Woeli Publishing Services.

Bombande, E. (2007). Conflicts, civil society organization and community peace building in Northern Ghana. In S. Tonah (Ed.), Ethnicity, conflicts and consensus in Northern Ghana (pp. 196-228). Accra, Ghana: Woeli Publishing Services.

Dixon, J. (1955). Report of Mr. J. Dixon, Administrative Officer Class I, on the representations made to the Trusteeship Council of the United Nations Organisation, concerning the status of the Nawuris and Nanjuros within the Togoland Area of the Gonja District. Accra, Ghana: Government of the Gold Coast.

Fortes, M., \& Evans-Pritchard, E.E. (1940). African Political Systems. Oxford, UK: Oxford University Press.

Hilton, T.E. (1962). Notes on the History of Kusasi. The Transactions of the Historical Society of Ghana VI, 79-86.

Jonssön, J. (2007). The overwhelming minority: Traditional leadership and ethnic conflict in Ghana's Northern Region. Centre for Research on Inequality, Human Security and Ethnicity (CRISE) Working Paper No. 30.

Ladouceur, P.A. (1979). Chiefs and politicians: The politics of regionalism in Northern Ghana. London, U.K.: Longman.

Lentz, C. (2007). Ethnicity and the making of history in Northern Ghana. Accra, Ghana: Woeli Publishing Services.

Lentz, C. \& Nugent, P. (Eds.). (2000). Ethnicity in Ghana: The limits of invention. London, UK: Macmillan. 
Lund, C. (2003). Bawku is still volatile: An ethno-political conflict and state recognition in Northern Ghana. Journal of Modern African Studies, 41(4), 587-610.

Maasole, C.S. (2006). The Konkomba and their neighbours from the pre-European period to 1914: A study in inter-ethnic relations in Northern Ghana. Accra, Ghana: Ghana Universities Press.

Mbowura, C.K. (2014). Security and conflict: Appraising and interrogating security arrangements in the Nawuri-Gonja conflict in Northern Ghana. International Journal of Development and Sustainability, 3 (7), 1502-1516.

Mbowura, C.K. (2013a). Constructing the Historicity of Chieftaincy among the Nawuri of Northern Ghana. Contemporary Journal of African Studies, 1(2), 21-44.

Mbowura, C.K. (2013b). Eat mangoes, grow cotton and be industrious: Interrogating German colonial rule in the Nawuri area of Northern Ghana, 1899 to 1914. In W. Apoh \& B. Lundt (Eds.), Germany and its West African colonies: Excavations of German colonialism in post-colonial times (pp. 201-220). Berlin, Germany: LIT.

Mbowura, C.K. (2012). Nawuri-Gonja conflict, 1932 to 1996. (PhD Thesis). University of Ghana, Legon.

Mbowura, C.K. (2002). Nawuri-Gonja relations, 1913-1994. (Master of Philosophy Thesis). University of Ghana, Legon.

Nachinaba, B. (2002. The religious life of the Kusasi of Bawku East. (M.A. Thesis). University of Ghana, Legon.

Rattray, R.S. 1932. The tribes of the Ashanti hinterland. Oxford, UK: Clarendon Press.

Richards P. (Ed). (2005). No peace no war: An anthropology of contemporary armed conflicts. Oxford: Ohio University Press \& James Curry.

Skalnik, P. (1989). Outwitting Ghana: Pluralism of political culture in Nanum. In P. Skalnik (Ed.), Outwitting the State (pp. 145-168). New Brunswick, NJ: Transaction Publishers.

Skalnik, P. (1983). Questioning the concept of the State in indigenous Africa. Social Dynamics, 9(2), 11-28.

Skalnik, P. (1987). On the inequality of the concept of the 'Traditional State.' Journal of Legal Pluralism and Unofficial Law 25 \& 26, 301-325.

Tonah, S. (2005). Resolving chieftaincy succession disputes and communal conflicts in Ghana: Lessons from Mamprugu, Northern Ghana. Legon Journal of International Affairs 2(1), 
Tuurey, G. (1982). An introduction to the Mole-speaking community. Wa, Ghana: Wa Catholic Press.

\section{Archives}

Public Records and Archival Division (PRAAD)

PRAAD (Accra) ADM 56/1/486, Annual Report for the Northern Territories for 1916

PRAAD (Accra) ADM 39/1/32, Notes on Krachi District

PRAAD (Accra) ADM 11/603, Notes on the People of Togoland

PRAAD (Accra) ADM 11/1/1621, Extract from Report of Enquiry on the Sphere of Occupation of Togoland

PRAAD (Accra) ADM 56/1/461 Bawku District: Report for the Month of December, 1917

PRAAD (Accra) ADM 56/1/219 Extract from the Chief Commissioner's Memorandum to His Excellency the Governor on Recruiting in the Northern Territories

PRAAD (Accra) ADM 56/1/258, Occupation of Yendi

PRAAD (Accra) ADM 39/1/32, "Letter from the District Commissioner of Kete-Krachi to the Provincial Commissioner of the Northern Territories", September, 1932

PRAAD (Tamale) NRG 8/2/210, Nawuri and Nchumuru under United Nations Trusteeship

PRAAD (Tamale) NRG 8/2/211, Enquiry Regarding the Claims of the Nawuri and Nchumuru: Advisory Committee

PRAAD (Tamale) NRG8/3/53, Report of the Northern Territories for the Year 1935-1936

PRAAD (Tamale) NRG 8/2/214, JKG Syme

PRAAD Accra, ADM 56/1/277, From Ag D. C. Kusasi to CNP, $7^{\text {th }}$ March, 1931.

PRAAD Accra, ADM 56/1/198 Ag. D C Bawku to C N E P 30 March, 1931.

PRAAD Accra, ADM 56/1/198, From Ag. D C Bawku/Kusasi to C N E P, 30 ${ }^{\text {th }}$ March, 1931

PRAAD Tamale, NRG8/2/138, Petition to the Government Agent in Gambaga by the Princes of Bawku and their Supporters Protesting against the Installation of Yeremea as Bawku Naba, $7^{\text {th }}$ June, 1957.

PRAAD Accra, ADM56/1/198, Statements made by those Chiefs and Sub-chiefs Holding Mamprusi Nam in Kusasi Concerning Investment by the Nayiri, $10^{\text {th }}$ January, 1933. 
Mbowura C. K. and Longi F. Y. T./ Legon Journal of the Humanities (2016) 172-195

PRAAD Accra, ADM 56/1/198, Extract from Diary of J.K.G

Syme, Asst. D.C. Bawku, $19^{\text {th }}$ December. 1932

Submitted: February 12, 2016 /Published: October 31, 2016 